\title{
The Swiss Tax System - Between Equality and Diversity
}

\author{
Peter Hänni
}

\section{Introduction ${ }^{1}$}

1.1

The Tax System as a Measure of State Autonomy

A central element of federal constitutional systems is their financial organisation. Anyone who wants to determine the degree of autonomy of the member states inevitably has to address the question of the financial autonomy of the various regional authorities. ${ }^{2}$ In this chapter, we will first analyse the constitutional framework with regard to the margin left to the subnational units in Switzerland in the field of taxation. We will show that they hold a considerable degree of autonomy, which leads to a number of consequences, among them a remarkable disparity between the cantons in terms of individual charges for taxpayers. In the following step, we will examine the system that Switzerland has set up to alleviate these inequalities, i.e. the constitutional rights of individual taxpayers (illustrated with cases decided upon by the Swiss Federal Supreme Court) and other constitutional limits of cantonal tax autonomy on the one hand, and the system of fiscal equalisation on the other hand. While fiscal equalisation aims to correct the disparities on an institutional level, taxpayers can directly invoke the individual constitutional guarantees and principles provided in the constitution.

\subsection{Public Expenditure in Switzerland}

One of the most striking features of Swiss federalism is the competence of the cantons to levy income taxes and to set tax rates. This fact is reflected in the statistics on federal, cantonal and communal expenditure, amongst others. The allocation of expenditure in the three-tier Swiss system highlighted in Table 9.1

1 I would like to thank Géraldine Cattilaz (MLaw) for her precious support in the completion of this contribution; I particularly benefited from her excellent English language skills for the final version.

2 Peter Hänni, "Commentary on Art. 135 FedCst.," in Basler Kommentar, Bundesverfassung, eds. Bernhard Waldmann, Eva Maria Belser and Astrid Epiney (Basel: Helbing Lichtenhahn, 2015), marginal no. 1. 
TABLE 9.1 Public expenditure in Switzerland 2016

Important figures according to the G FS Model

\begin{tabular}{|c|c|c|c|c|c|c|}
\hline CHF mn & & 2012 & 2013 & 2014 & 2015 & 2016 \\
\hline \multirow{5}{*}{$\begin{array}{l}\text { General } \\
\text { government }\end{array}$} & Revenue & 203,941 & 208,762 & 210,864 & 219,115 & 220,177 \\
\hline & Expenditure & 201,547 & $211,5 \mathrm{O} 1$ & 212,257 & 214,896 & 217,703 \\
\hline & Net lending/borrowing & 2,394 & $-2,739$ & $-1,392$ & 4,219 & 2,474 \\
\hline & Tax-to-GD P ratio & 27.0 & 27.1 & 26.9 & 27.6 & 27.8 \\
\hline & Debt ratio (Maastricht) ${ }^{2}$ & 30.6 & 30.3 & 30.6 & 30.0 & 29.0 \\
\hline \multirow[t]{5}{*}{ Confederation $^{1}$} & Revenue & 65,814 & 67,965 & 67,292 & 71,726 & 71,571 \\
\hline & Expenditure & 64,737 & 67,039 & 67,294 & 69,138 & 70,600 \\
\hline & Net lending/borrowing & $\mathbf{1 , 0 7 7}$ & 926 & -1 & 2,588 & 971 \\
\hline & Tax-to-GD P ratio & $9 \cdot 5$ & 9.6 & $9 \cdot 4$ & $9 \cdot 9$ & 9.8 \\
\hline & Debt ratio (Maastricht) ${ }^{2}$ & 16.8 & 16.4 & 15.8 & 15.0 & 14.0 \\
\hline \multirow[t]{5}{*}{ Cantons } & Revenue & 82,728 & 84,303 & 85,762 & 89,190 & 90,320 \\
\hline & Expenditure & 83,576 & 88,657 & 87,724 & 88,8 o3 & 89,426 \\
\hline & Net lending/borrowing & -848 & $-4,353$ & $-1,962$ & 387 & 894 \\
\hline & Tax-to-GDP ratio & 6.7 & 6.7 & 6.7 & 6.8 & 7.0 \\
\hline & Debt ratio (Maastricht) & $7 \cdot 3$ & $7 \cdot 5$ & 8.3 & 8.4 & 8.4 \\
\hline \multirow[t]{5}{*}{ Municipalities } & Revenue & 43,493 & 44,041 & 45,093 & 46,221 & 47,026 \\
\hline & Expenditure & 44,238 & 45,407 & 46,714 & 46,631 & 47,160 \\
\hline & Net lending/borrowing & -745 & $-1,367$ & $-1,621$ & -410 & -133 \\
\hline & Tax-to-GDP ratio & 4.1 & 4.1 & 4.1 & 4.2 & $4 \cdot 3$ \\
\hline & Debt ratio (Maastricht) ${ }^{2}$ & 6.5 & 6.6 & 6.7 & 6.8 & 6.7 \\
\hline \multirow{5}{*}{$\begin{array}{l}\text { Social security } \\
\text { funds }\end{array}$} & Revenue & 59,141 & 60,185 & 61,426 & 61,836 & 62,351 \\
\hline & Expenditure & 56,230 & $5^{8,131}$ & 59,233 & 60,181 & $61,6 \circ 9$ \\
\hline & Net lending/borrowing & 2,911 & 2,055 & 2,192 & 1,654 & 742 \\
\hline & Tax-to-GDP ratio & 6.7 & 6.7 & 6.6 & 6.7 & 6.7 \\
\hline & Debt ratio (Maastricht) ${ }^{2}$ & 1.0 & 0.7 & 0.6 & 0.4 & 0.4 \\
\hline
\end{tabular}

\footnotetext{
1 incl. separate accounts

2 according to the Maastricht definition

SOURCE: FEDERAL FINANCE ADMINISTRATION AND FEDERAL STATISTIC OFFICE
} 
shows that in 2015, the Confederation spent roughly $26 \%$ of the total public expenditure, the cantons $34 \%$ and the municipalities ${ }^{3} 17 \%$. The expenditure for social insurances (which lies in the hands of the Confederation) amounts to $23 \%$. Even the share of total public spending shows that the cantons have a strong financial position. Below, we will look at the constitutional reasons which enable the cantons to exercise such fiscal strength.

\section{The Constitutional Framework}

\subsection{The Power to Levy Direct Taxes: The Federal and the Cantonal Level}

The Swiss tax system is laid down in the Federal Constitution (FedCst). Given that the Swiss Constitution provides the so-called presumption of autonomy in favour of the cantons, any Federal competence needs a constitutional basis. ${ }^{4}$ This is particularly true when we deal with the power to levy taxes. While value added taxes (VAT), special consumption taxes, the stamp duty, and withholding tax and customs duties are codified in the Federal Constitution as exclusive competences of the Federal state, ${ }^{5}$ the situation is fundamentally different in the field of direct taxes. Indeed, the Confederation as well as the cantons hold the competence to levy direct taxes. ${ }^{6}$ The relevant article in the FedCst reads as follows:

Art. 128 FedCst.

1 The Confederation may levy a direct tax:

a. of a maximum of 11.5 per cent on the income of private individuals;

b. of a maximum of 8.5 per cent of the net profit of legal entities;

c. $[\ldots]$

3 As there is no difference in Switzerland between municipalities and communes, both terms will be used in this chapter.

4 Cf. Art. 3 FedCst.: 'The Cantons are sovereign except to the extent that their sovereignty is limited by the Federal Constitution. They exercise all rights that are not vested in the Confederation'; see also, amongst others, for the context of taxation: Jean-François Aubert, "Commentary on Chapter 3 FedCst.," in Petit Commentaire de la Constitution fédérale de la Confédération suisse, eds. Jean-François Aubert and Pascal Mahon (Zurich, Basel, Geneva: Schulthess, 2003), marginal no. 2; Urs Behnisch, "Commentary on Art. 127 FedCst.," in Basler Kommentar, Bundesverfassung, eds. Bernhard Waldmann, Eva Maria Belser and Astrid Epiney (Basel: Helbing Lichtenhahn, 2015), marginal no. 4.

5 Cf. Art. 130-133 FedCst.

6 Giovanni Biaggini, Kommentar zur Bundesverfassung der Schweizerischen Eidgenossenschaft (Zurich: Orell Füssli, 2017), Art. 128 marginal no. 3. 
2 The Confederation, in fixing the taxation rates, shall take account of the burden of direct taxation imposed by the Cantons and communes.

3 In relation to the tax on the income of private individuals, regular revisions shall be made to compensate for the consequences of an increased tax burden due to inflation.

4 The tax is assessed and collected by the Cantons. A minimum of 17 per cent of the gross revenue from taxation is allocated to the Cantons. This share may be reduced to 15 per cent if the consequences of financial equalisation so require.

The constitutional right of the Confederation to levy direct taxes on income or net income is not of a binding nature, either in principle or with regard to the exact extent of the taxes imposed. ${ }^{7}$ However, the constitution sets binding limits as to the maximal burden imposed on tax payers by federal taxes. ${ }^{8}$ These limits are set relatively low at $11.5 \%$ for natural persons and $8.5 \%$ for legal persons. The fact that the upper limits are enshrined in the Constitution in numerical terms means that the cantons' scope for tax planning is very effectively protected, ${ }^{9}$ because if the Confederation wished to raise these upper limits, it would have to overcome the hurdle of a double majority of voters and cantons within the framework of the obligatory constitutional referendum - an almost insurmountable task. If these limits were not codified in the Federal Constitution, the federal legislator could be inclined to claim the tax substrate of the cantons - through a continuous increase in the direct federal tax - to such an extent that the financial autonomy of the cantons would ultimately be such in name only. ${ }^{10}$

These considerations (notwithstanding the constitutional provisions on tax harmonisation) show that the cantons are granted extensive autonomy in levying direct cantonal taxes. ${ }^{11}$ This autonomy is further protected by Art. 129 Constitution fédérale de la Confédération suisse, eds. Jean-François Aubert and Pascal Mahon (Zurich, Basel, Geneva: Schulthess, 2003), marginal no. 6; Biaggini, Kommentar zur Bundesverfassung, Art. 128 marginal no. 3 .

8 Klaus A. Vallender and Ulrich Cavelti, "Commentary on Art. 128 FedCst.," in Die schweizerische Bundesverfassung, St. Galler Kommentar, eds. Bernhard Ehrenzeller et al. (Zurich, St. Gallen: Schulthess, 2014), Art. 128 marginal no. 2.

9 Biaggini, Kommentar zur Bundesverfassung, Art. 128 marginal no. 3; Madeleine Simonek, "Commentary on Art. 128 FedCst.," in Basler Kommentar, Bundesverfassung, eds. Bernhard Waldmann, Eva Maria Belser and Astrid Epiney (Basel: Helbing Lichtenhahn, 2015), marginal no. 7 .

10 Hänni, "Commentary on Art. 135 FedCst.," marginal no. 1.

11 Biaggini, Kommentar zur Bundesverfassung, Art. 128 marginal no. 3; Hänni, “Commentary on Art. 135 FedCst.," marginal no. 1. 
para. 2 FedCst., which explicitly excludes tax tariffs, tax rates and tax allowances from federal competence within the framework of tax harmonisation. Indirect protection of cantonal financial autonomy is also based on the constitutional regulation of value-added tax, because even in this area - which is reserved for the Confederation - the constitution contains, in comparison to international standards, a relatively low upper limit for the tax burden (cf. Art. 130 para. 1 FedCst.).

Due to the cantons' subsidiary general competence, the tax competences of the cantons can be described in simplified terms as the sum of the competences not claimed by the Confederation in this area. ${ }^{12}$ In this regard, it is important to keep in mind the constitutional exclusion of cantonal and communal taxation codified in Art. 134 FedCst. This exclusion is made effective by federal legislation: insofar as federal legislation declares a taxable event to be subject to or exempt from VAT, special consumption taxes, stamp duty and withholding tax, the cantons may not burden such an event with similar taxes (Art. 134 FedCst.). Generally speaking, however, the cantons have considerable room for manoeuvre. ${ }^{13}$ All cantons tax the income and assets of natural persons and levy taxes on profits and capital of legal entities. Inheritance and gift taxes, motor vehicle taxes, property gains and transfer taxes are also widespread. However, increased tax competition has recently led inheritance and gift taxes in particular to be questioned. In various cantons, these types of taxes have been abolished or their scope considerably restricted.

\subsection{Modalities for the Levying of Direct Federal Taxes}

Pursuant to para. 2 of Art. 128 FedCst., the Confederation must take into account the burden of the direct taxes of the cantons and municipalities when setting the tax rates. ${ }^{14}$ However, this provision is more of an appeal to the federal legislator to keep a low profile. Legal consequences cannot be derived from it. ${ }^{15}$

The FedCst. outlines the need to adjust the burden to taxpayers caused by inflation as a result of the progressive structure of the tax rates, this is termed as cold progression and is outlined in Art. 128 FedCst. ${ }^{16}$ If this compensation were not achieved and the tax rates for the income of natural persons remained

\footnotetext{
12 Markus Reich, Steuerrecht (Zurich: Schulthess, 2012), chapter 4 marginal no. 8.

13 Biaggini, Kommentar zur Bundesverfassung, Art. 128 marginal no. 3.

14 See also: Simonek, "Commentary on Art. 128 FedCst.," marginal no. 18; Vallender and Cavelti, "Commentary on Art. 128 FedCst.," marginal no. 25.

15 Aubert, "Commentary on Art. 128 FedCst.," marginal no. 11; Vallender and Cavelti, "Commentary on Art. 128 FedCst.," marginal no. 26.

16 Aubert, "Commentary on Art. 128 FedCst.," marginal no. 12; Vallender and Cavelti, "Commentary on Art. 128 FedCst.," marginal no. 18.
} 
the same (cold progression), the tax burden would increase disproportionally compared to purchasing power. ${ }^{17}$

Direct federal tax is assessed (determination of the tax in individual cases by decree) and collected by the cantons (Art. 128 para. 4 sentence 1 FedCst.); enforcement is therefore the responsibility of the cantons. Accurate processing by the cantons is ensured by special federal supervisory and control powers provided for by law. ${ }^{18}$

$17 \%$ of the gross income from the direct federal tax is assigned to the cantons as a so-called cantonal share (Art. 128 para. 4 FedCst.). This cantonal share has historical roots, since the competence of the Confederation to levy direct federal taxes was only introduced in 1915 and against significant resistance from the cantons. ${ }^{19}$ This historical context also explains the continuing temporal limits imposed on the Confederation's competence to levy direct federal taxes (Art. 196 para. 13 FedCst., the current period expired at the end of 2020 and needs to be renewed). ${ }^{20}$

\subsection{Municipal Taxes in the Swiss Federal State}

When comparing federal, cantonal and municipal budget expenditure (excluding social security contributions), we find that municipalities account for around $17 \%$ of government expenditure (see Table 9.1 above). To cover these expenditures, municipalities have various kinds of revenues at their disposal, but municipal taxes in Switzerland are by far the main source of income for municipal spending.

The existence of municipalities is not mandatory under the Federal Constitution, nor is the way in which they are financed. The communes do not have any original taxing powers, but rather are granted such powers by the cantons. ${ }^{21}$ Such a delegation of taxing powers to municipalities has taken place in all cantons, either at the (cantonal) constitutional level or (above all) through cantonal tax laws. The municipalities are therefore not authorised

17 Biaggini, Kommentar zur Bundesverfassung, Art. 128 marginal no. 8; Vallender and Cavelti, "Commentary on Art. 128 FedCst.," marginal no. 17.

18 See the provisions in the DBG (the federal law on direct federal taxes); see also: Biaggini, Kommentar zur Bundesverfassung, Art. 128 marginal no. 9; Simonek, "Commentary on Art. 128 FedCst.," marginal no. 23; Vallender and Cavelti, "Commentary on Art. 128 FedCst.," marginal no. 32 .

19 Biaggini, Kommentar zur Bundesverfassung, Art. 128 marginal no. 10.

$20 \quad$ Vallender and Cavelti, "Commentary on Art. 128 FedCst.," marginal no. 34.

21 Urs Behnisch, "Commentary on Art. 129 FedCst.," in Die schweizerische Bundesverfassung, St. Galler Kommentar, eds. Bernhard Ehrenzeller et al. (Zurich, St. Gallen: Schulthess, 2014), marginal no. 6; Reich, Steuerrecht, chapter 4 marginal no. 11. 
under federal constitutional law to levy taxes; this competence is regularly granted to them by cantonal law. ${ }^{22}$ Nevertheless, the municipalities are bound by all federal law requirements without further specification.

Consequences for Individual Taxpayers: Large Differences in the Tax Burden

As explained above, in the three-tiered federal state (with a few exceptions), individual taxpayers have to pay taxes on their income and assets at three different levels: the federal, cantonal and municipal. ${ }^{23}$ Since the Federal Constitution explicitly guarantees the canton the right to set tax rates, ${ }^{24}$ there exists - in practice - considerable differences in the tax burden for the individual taxpayer, depending on the canton in which they are domiciled. Figures 9.1 and 9.2 show these differences in direct taxes at the cantonal level.

As explained above, due to the federalist structure of the Swiss tax systems, cantons and communes can have parallel competences to levy taxes. In addition to delegating taxing powers to communes, cantons can also delegate taxing powers to other entities, such as the church. Some churches therefore exercise their right to levy taxes, which is why this these graphs also take into account church taxes. ${ }^{25}$

\section{Constitutional Measures in Favour of Equality}

\subsection{Introduction}

As we have seen, the tax autonomy of the cantons (and the municipalities) leads to large disparities concerning the tax burden of individual taxpayers. In this context and to address the risk of incoherent and unjust situations for individuals as a consequence of their choice of canton or municipality in which to live, the federal constitutional law has set up a series of measures to protect taxpayers from extreme disparities. In this section, we will present and discuss these measures.

\footnotetext{
22 Reich, Steuerrecht, chapter 4 marginal nos. 11 et seq.

23 Chapter 3; see also: Behnisch, "Commentary on Art. 129 FedCst.," marginal no. 5.

24 See Art. 129 para. 2 of the Federal Constitution: 'Harmonisation shall extend to tax liability, the object of the tax and the tax period, procedural law and the law relating to tax offences. Matters excluded from harmonisation shall include in particular tax scales, tax rates and tax allowances.'

See for example Reich, Steuerrecht, chapter 4 marginal no. 11 et seq.
} 


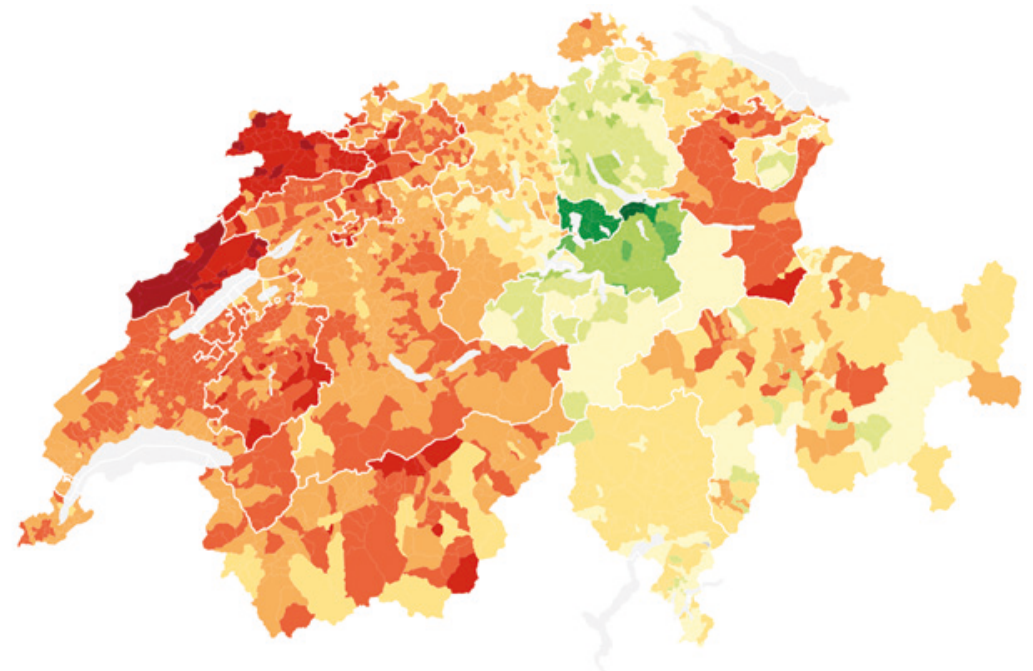

Tax burden expressed as percentage of the gross earned income (cantonal, communal and church taxes)

$\begin{array}{lllllllll}17.4 \% & 16.0 \% & 14.6 \% & 13.2 \% & 11.8 \% & 10.4 \% & 9.0 \% & 7.6 \% & 6.2 \%\end{array}$

FIGURE 9.1 Tax burden for a single taxpayer without children (income: CHF 100'OOO) in 2015

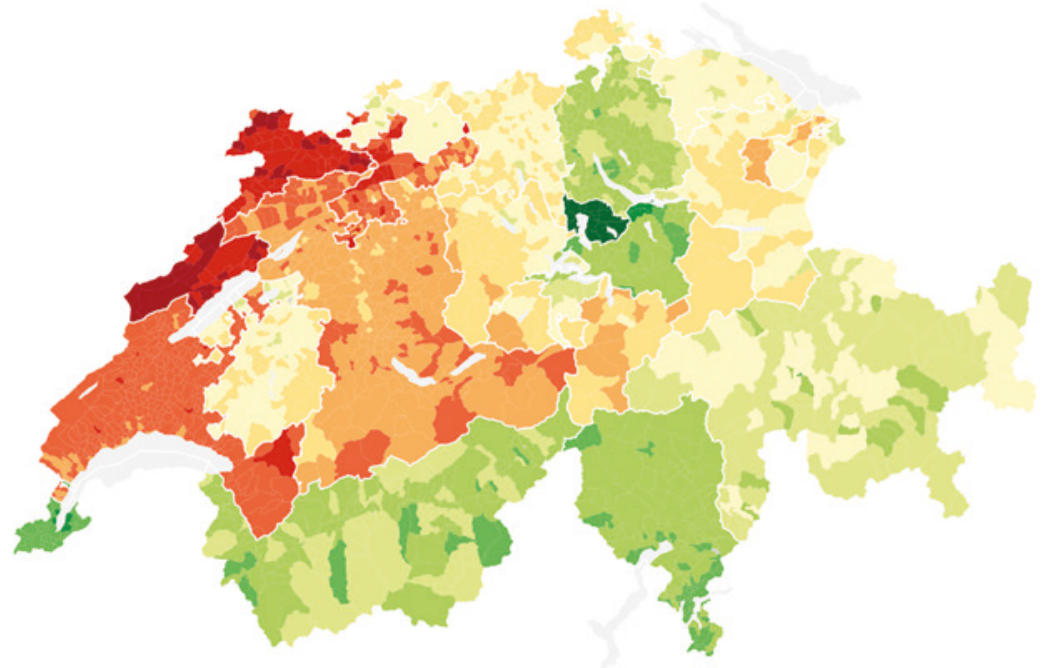

Tax burden expressed as percentage of the gross earned income (cantonal, communal and church taxes)

\begin{tabular}{lllllllll}
\hline $9.6 \%$ & $8.7 \%$ & $7.8 \%$ & $7.0 \%$ & $6.1 \%$ & $5.2 \%$ & $4.3 \%$ & $3.4 \%$ & $2.5 \%$
\end{tabular}

FIGURE 9.2 Tax burden for a married taxpayer with two children (income: CHF 100'OOO) in 2015 


\subsection{Principles of Tax Law \\ 4.2.1 Meaning and Scope}

The tax-law principles are, on the one hand, binding for the legislative authorities and represent guidelines for the content of tax-law enactments. ${ }^{26}$ On the other hand, however, they are also of an individual-law nature, in that they confer (individual) constitutional rights (in the determination of public-law levies) to taxpayers. ${ }^{27}$

According to the Federal Constitution, these principles apply primarily to federal taxes and levies, but the case law of the Federal Supreme Court leaves no doubt that they are also applicable to cantonal taxes and levies, as they were developed by the Federal Supreme Court in the area of cantonal tax and levies legislation before they were anchored in the Federal Constitution. ${ }^{28}$

4.2.2 The Principles in Detail

(a) The Principle of Legality

The principle of legality in the context of tax law is enshrined in Art. 127 para. 1 FedCst. and requires that 'the basic features of the tax structure, in particular the group of taxpayers, the object of the tax and its assessment' must be regulated in the law itself. The validity of the principle of legality for taxes in general results from Art. 164 para. 1 lit. d FedCst., ${ }^{29}$ which stipulates that all important legislative provisions are to be enacted in the form of a federal law. These include, in particular, the basic provisions on the group of taxpayers and the object and assessment of levies. However, a certain attenuation of this principle is permissible in the case of causal levies. ${ }^{30}$

26 Reich, Steuerrecht, chapter 4 marginal no. 122; Klaus A. Vallender and René Wiederkehr, "Commentary on Art. 127 FedCst.," in Die schweizerische Bundesverfassung, St. Galler Kommentar, eds. Bernhard Ehrenzeller et al. (Zurich, St. Gallen: Schulthess, 2014), marginal no. 4 .

27 Instead of many: Biaggini, Kommentar zur Bundesverfassung, Art. 127 marginal no. 7; Reich, Steuerrecht, chapter 4 marginal no. 122.

28 Behnisch, "Commentary on Art. 127 FedCst.," marginal nos. 3 and 17; for a slightly different line of argument see: Jean-François Aubert, "Commentary on Art. 127 FedCst.," in Petit Commentaire de la Constitution fédérale de la Confédération suisse, eds. Jean-François Aubert and Pascal Mahon (Zurich, Basel, Geneva: Schulthess, 2003), marginal no. 4; Kommentar zur Bundesverfassung, Art. 127 marginal no. 8.

29 Aubert, "Commentary on Art. 127 FedCst.," marginal no. 5; Behnisch, "Commentary on Art. 127 FedCst.," marginal no. 3; Vallender and Wiederkehr, "Commentary on Art. 127 FedCst.," marginal no. 5 .

30 The principle of legality was first developed in the American Revolution and became famous in the formulation of 'No taxation without representation'; see also: Behnisch, "Commentary on Art. 127 FedCst.," marginal no. 17; Biaggini, Kommentar zur Bundesverfassung, Art. 127 marginal no. 6. 
The term 'law' refers to a law in the formal sense, ${ }^{31}$ i.e. a general-abstract decree that was passed within the framework of the ordinary legislative procedure. ${ }^{32}$ The law itself must therefore regulate the group of persons subject to tax or duty (subject of tax or duty), the object of the tax or duty (e.g. income, assets, turnover, consumption) and the assessment of taxes or duties (tax tariffs, tax rates, timing). ${ }^{33}$ According to federal constitutional law, the executive branch must not legislate on these subject matters. ${ }^{34}$

In addition to these requirements, the fact that a law in the formal sense is necessary also leads to any tax law (be it federal, cantonal or communal) necessarily being subject to an optional or mandatory referendum. ${ }^{35}$ One can easily imagine that any proposal by the government and/or the parliament for higher (or lower) taxes only passes in a popular vote if it is carefully designed and if it can be justified by an overriding public interest. It is not enough for powerful interest groups to support the project.

\section{Principles of Taxation}

In addition to the principle of legality, the legislative authorities must comply with certain taxation principles when structuring taxes. Pursuant to Art. 127 para. 2 FedCst. 'in particular, the principles of generality and uniformity of taxation as well as the principle of taxation on the basis of economic capacity must be observed' - and this to the extent permitted by the nature of the tax. ${ }^{36}$ The taxation principles, as explained above, represent enforceable constitutional individual rights, which the Federal Supreme Court had developed from the principle of equality of law in many years of jurisprudence prior to the entry into force of the now applicable FedCst. in 2000. ${ }^{37}$

\section{The Principle of Universality}

The principle of universality of taxation is intended to prevent both unjustified privileges for and discrimination against individual taxpayers or certain

\footnotetext{
31 Instead of many: Aubert, "Commentary on Art. 127 FedCst.," marginal no. 5.

32 Instead of many: Pierre Tschannen, Ulrich Zimmerli and Markus Müller, Allgemeines Verwaltungsrecht (Bern: Stämpfli, 2014), chapter 13 marginal nos. $2 \mathrm{f}$.

33 Behnisch, "Commentary on Art. 127 FedCst.," marginal no. 6; Biaggini, Kommentar zur Bundesverfassung, Art. 127 marginal no. 6.

34 Biaggini, Kommentar zur Bundesverfassung, Art. 127 marginal no. 3; Vallender and Wiederkehr, "Commentary on Art. 127 FedCst.," marginal no. 7.

35 Vallender and Wiederkehr, "Commentary on Art. ${ }_{127}$ FedCst.," marginal no. 9.

36 Biaggini, Kommentar zur Bundesverfassung, Art. 127 marginal no. 9.

37 Behnisch, "Commentary on Art. 127 FedCst.," marginal no. 18; Biaggini, Kommentar zur Bundesverfassung, Art. 127 marginal no. 7 .
} 
groups of persons. ${ }^{38}$ However, the principle of universality only excludes exceptions for general taxes, but not for objectively justified special taxes (e.g. special excise duties). ${ }^{39}$ Historically, tax privileges were widespread in Switzerland. 40

\section{The Principle of Uniformity}

The principle of uniformity of taxation ensures that identical or comparable situations are treated equally. ${ }^{41}$

\section{The Principle of Taxation According to Economic Capacity}

The principle of taxation according to economic capacity is intended to take into account the fact that the same tax rate for all leads to proportionally unequal charges. ${ }^{42}$ This makes progressive - i.e. disproportionately increasing - taxation of income taxes permissible, in complete contrast to digressively structured tax rates. ${ }^{43}$ However, it must be borne in mind that the legislator has left considerable room for manoeuvre to the authorities applying the principle of taxation according to economic capacity, because this principle is a concept that requires a great deal of interpretation.

\section{Prohibition of Inter-Cantonal Double Taxation}

Finally, another principle of taxation is the prohibition of inter-cantonal double taxation (Art. 127 para. 3 FedCst.). Such inter-cantonal double taxation would be possible in a federal state that grants the member states considerable tax powers for autonomous structuring (as is the case in Switzerland). ${ }^{44}$ Double taxation occurs when the tax subject, tax object, tax period and tax

38 Reich, Steuerrecht, chapter 4 marginal no. 126; Vallender and Wiederkehr, "Commentary on Art. 127 FedCst.", marginal nos. 12 et seq.

39 Vallender and Wiederkehr, "Commentary on Art. 127 FedCst.," marginal no. 18.

40 For the whole paragraph see: Behnisch, "Commentary on Art. 127 FedCst.," marginal no. 24: Biaggini, Kommentar zur Bundesverfassung, Art. 127 marginal no. 10.

41 Aubert, "Commentary on Art. 127 FedCst.," marginal no. 9; Behnisch, "Commentary on Art. 127 FedCst.," marginal no. 27; Biaggini, Kommentar zur Bundesverfassung, Art. 127 marginal no. 11; Vallender and Wiederkehr, "Commentary on Art. 127 FedCst.," marginal no. 21 .

42 Biaggini, Kommentar zur Bundesverfassung, Art. 127 marginal no. 12; Reich, Steuerrecht, chapter 4 marginal no. 139 .

43 See the case law below.

44 Aubert, "Commentary on Art. 127 FedCst.," marginal no. 12; Behnisch, "Commentary on Art. 127 FedCst.," marginal no. 48; Biaggini, Kommentar zur Bundesverfassung, Art. 127 marginal no. 14; Reich, Steuerrecht, chapter 4 marginal no. 14. 
type are identical. ${ }^{45}$ In principle, only taxes are covered, but not so-called causal taxes (for example fees). ${ }^{46}$ The double taxation prohibition constitutes an enforceable constitutional individual right as well. ${ }^{47}$ At the same time, it obliges the Confederation to adopt the necessary measures. ${ }^{48}$

\subsection{Tax Harmonisation}

As mentioned above, due to the considerable autonomy of the cantons in the area of taxation, direct taxes are structured very differently according to the canton (or commune) ${ }^{49}$ In order to place at least some aspects of taxation on a comparable footing, Article 129 para. 1 of the FedCst. confers on the Confederation the authority to lay down principles to harmonise direct taxes of the Confederation, the cantons and the communes. This competence is thus a mandate for so-called basic legislation, with the aim of harmonising rather than standardising. ${ }^{50}$ The mandate covers only direct taxes, primarily income and wealth taxes or taxes on profits and capital. ${ }^{51}$ Still, this formal tax harmonisation creates a basis for the comparability of the tax burden, which in the past was nearly impossible even in purely conceptual terms due to an almost incomprehensible diversity.

Art. 129 para. 2 FedCst. specifies the object of harmonisation. According to this provision, tax harmonisation extends 'to tax liability, subject matter and temporal assessment of taxes, procedural law and criminal tax law. Tax tariffs, tax rates and tax allowances in particular are exempt from harmonisation'.

45 Behnisch, "Commentary on Art. 127 FedCst.," marginal no. 54; Biaggini, Kommentar zur Bundesverfassung, Art. 127 marginal no. 16; Vallender and Wiederkehr, "Commentary on Art. 127 FedCst.," marginal no. 71.

46 Behnisch, "Commentary on Art. 127 FedCst.," marginal no. 55; Biaggini, Kommentar zur Bundesverfassung, Art. 127 marginal no. 16.

47 Behnisch, "Commentary on Art. 127 FedCst.," marginal no. 52; Biaggini, Kommentar zur Bundesverfassung, Art. 127 marginal no. 14; Reich, Steuerrecht, chapter 4 marginal no. 17; Vallender and Wiederkehr, "Commentary on Art. 127 FedCst.," marginal no. 59.

48 Behnisch, "Commentary on Art. 127 FedCst.," marginal no. 53; Biaggini, Kommentar zur Bundesverfassung, Art. 127 marginal no. 15; Reich, Steuerrecht, chapter 4 marginal no. 17; Vallender and Wiederkehr, "Commentary on Art. 127 FedCst.," marginal no. 59.

49 Chapter 4; see also Jean-François Aubert, "Commentary on Art. 129 FedCst.," in Petit Commentaire de la Constitution fédérale de la Confédération suisse, eds. Jean-François Aubert and Pascal Mahon (Zurich, Basel, Geneva: Schulthess, 2003), marginal no. 2; Behnisch, "Commentary on Art. 129 FedCst.," marginal no. 7.

50 Biaggini, Kommentar zur Bundesverfassung, Art. 129 marginal no. 2; for a detailed discussion of different forms of harmonisation: Aubert, "Commentary on Art. 129 FedCst.," marginal nos. 2 et seq.

51 Behnisch, "Commentary on Art. 129 FedCst.," marginal no. 12; Biaggini, Kommentar zur Bundesverfassung, Art. 129 marginal no. 4. 
This means that three fundamental areas remain excluded from harmonisation, which is why the autonomy of the cantons in (substantive) core areas of tax legislation is not affected by harmonisation measures and on the contrary even enjoys explicit constitutional protection. ${ }^{52}$ However, there are reservations regarding compliance with the principles of taxation outlined above.

Finally, Art. 129 para. 3 FedCst. grants the Confederation a limited, nonbinding legislative competence to enact regulations against unjustified tax advantages. However, the Confederation has not to date made use of the associated powers of intervention. ${ }^{53}$

In the following section, we will illustrate the individual rights of taxpayers explained above by analysing two recent cases decided by the Swiss Federal Supreme Court.

\section{Case Law: The Constitutional Limits of Cantonal Tax Autonomy}

\subsection{The Case of Regressive Tariffs in the Canton of Obwalden}

In a landmark decision that received much attention, the Federal Supreme Court dealt with the issue of regressive tax rates. These fundamental considerations were prompted by a new tax law of the Canton of Obwalden, which provided for the following tax burdens on income (Table 9.2, below).

TABLE 9.2 Provided tax burdens on income by the tax law of the Canton of Obwalden

\begin{tabular}{lll}
\hline Income & Simple tax & $\begin{array}{l}\text { Tax burden in } \\
\text { percentage }\end{array}$ \\
\hline
\end{tabular}

$\begin{array}{lll}\text { CHF } & \text { CHF } & \\ 5,000- & \mathrm{O}- & 0 \\ 10,000- & 45^{-} & 0.45 \\ 20,000- & 183- & 0.915 \\ 30,000- & 385- & 1.2833 \\ 50,000- & 837- & 1.674\end{array}$

$5^{2}$ Biaggini, Kommentar zur Bundesverfassung, Art. 129 marginal no. 6; Madeleine Simonek, "Commentary on Art. 129 FedCst.," in Basler Kommentar, Bundesverfassung, eds. Bernhard Waldmann, Eva Maria Belser and Astrid Epiney (Basel: Helbing Lichtenhahn, 2015), marginal no. 11. 
TABLE 9.2 Provided tax burdens on income by the tax law of the Canton of Obwalden (cont.)

\begin{tabular}{lll}
\hline Income & Simple tax & $\begin{array}{l}\text { Tax burden in } \\
\text { percentage }\end{array}$ \\
\hline 100,000 - & $2,002-$ & 2.002 \\
$200,000-$ & $4,352-$ & 2.176 \\
$300,000-$ & $6,702-$ & 2.234 \\
$400,000-$ & $8,342-$ & 2.0855 \\
$550,000-$ & $9,882-$ & 1.7967 \\
$1,000,000-$ & $16,882-$ & 1.6882 \\
$2,000,000-$ & $33,382-$ & 1.6691 \\
\hline
\end{tabular}

The Federal Supreme Court ruled that this regressive tax burden does not conform to the constitution:

9.3 The new Obwalden tax rate is regressive only for taxable income of CHF 300,000 or more. Nevertheless, in some sections it causes burden differences that can no longer be described as insignificant. For example, the average tax burden on a taxable income of CHF $300,000(2.2340)$ is 32.33 per cent higher than the average tax burden on an income of $\mathrm{CHF}$ 1,O०O,OOO (1.6882). With a taxable income of CHF 200,000 (2.1760), the average tax rate is 28.89 per cent higher than with a taxable income of $\mathrm{CHF} 1,000,000$. Even with an income of CHF 100,000 (2.0020), the average tax burden is still 18.58 per cent higher than with an income of CHF 1,OOo,ooo. In effect, the average tax burden for an income of $\mathrm{CHF}$ 1,000,00O (1.6882) is practically the same as for an income of CHF 51,200 (1.6887).

The differences in tax burden shown do not stand up to the principle of equal taxation and the principle of taxation according to economic performance. These require that the burden of each income level within the system and in comparison with the other income levels be carried out according to the same rules, appear objectively justified and in a reasonable proportion [...]. The claim is central, especially since comparability in the vertical direction is made more difficult and equality of law and tax justice cannot be established in any other way.

Moreover, the canton does not claim that the taxation according to the principle of efficiency requires a regressive tariff process. Rather, the reason for this tariff structure was other (fiscal or non-fiscal) motives, as can also be seen from the legal opinion of Prof. Reich on the question of 
the constitutionality of the Obwalden income and wealth tax tariff of 18 April 2006 submitted by the cantonal Government [...]. The reference to the regressive tariff design merely compensating for the progression of the direct federal tax does not justify its unconstitutionality, especially as the cantonal tax must also comply with the principle of efficiency.

The contested income tax tariff therefore violates the principle of taxation according to economic capacity (Art. 127 para. 2 FedCst.) as well as the general principle of equality (Art. 8 para. 1 FedCst.) insofar as it provides for a lower average tax rate for higher incomes than for lower incomes. ${ }^{54}$

\subsection{Tax Amnesty in the Canton of Ticino}

5.2.1 The Factual Basis of the Case

On 25 November 2013, the Grand Council of the Canton of Ticino (Parliament) decided to introduce the following provisions into the transitional provisions of the Ticino tax law of 21 June 1994:

Art. 309e (new) Reduced rates in the case of self-disclosure without penalty

1 The rates applied to the recovery of uncollected tax in accordance with Article 236(1) in respect of exempt self-declarations submitted from 1 January of entry into force to 31 December of the year following entry into force shall be reduced by 70 per cent. On the elements already taxed, the reduction is applied to the increase in the marginal rate.

2 The reduction in rates shall be applied when the conditions of Article 258(3) (self-disclosure without penalty) are fulfilled.

3 Reduced rates are not allowed for the creation of untaxed hidden reserves.

4 The reduction in the rates referred to in paragraph 1 shall be permitted only in respect of deducted items which have not been declared to the tax authority by $3_{1}$ December of the year preceding their entry into force.

Art. 314e (new) Reduced rates for self-disclosure without penalty.

1 The rates applied to the recovery of uncollected tax pursuant to Article 236 (1), in respect of exempt self-declarations submitted from 1 January of the entry into force to 31 December of the year following the entry into force, shall be reduced by 70 per cent.

2 The reduced rates are only applicable if the conditions of Article $265 \mathrm{a}$ (1) (self-disclosure without penalty) are met. 
3 Reduced rates are not permitted in connection with the creation of untaxed hidden reserves.

4 The reduction in the rates referred to in paragraph 1 shall be permitted only in respect of stolen items which have not been declared to the tax authority by 31 December of the year preceding their entry into force.

The new law, which concerns natural persons (art. 3oge LT) and legal persons (art. 314e LT), was published in the Cantonal Official Gazette on 29 November 2013 with an indication of the deadline for exercising the right of referendum. Accepted by the people of Ticino, after a successful referendum had been launched against it, the law was then published in the Official Bulletin of the laws and executive acts of the Canton of Ticino of 4 July 2014.

The plaintiffs addressed the Federal Supreme Court with regards to the new law, doing so for two separate reasons:

On the one hand, they claimed the violation of the principle of the primacy of federal law (Art. 49 FedCst.), questioning the compatibility of the contested provisions with those of the relevant federal law on tax harmonisation that was voted on by the Federal Assembly on 20 March 2008. They also challenged the exercise of powers by the Ticino legislature with regard to tariffs and tax rates (Art. 129 para. 2 FedCst.).

On the other hand, they claimed that the rules had an unlawful retroactive effect (Art. 5 para. 1 FedCst.) and that they were contrary to both the principle of legal equality (Art. 8 para. 1 FedCst.) and the principles of universality, uniformity and taxation according to economic capacity (Art. 127 para. 2 FedCst.), without there being sufficient grounds to justify such violations.

\subsubsection{The Reasoning of the Court}

With respect to the first argument invoked by the plaintiffs, the court shared their opinion that the cantonal law was inconsistent with the Federal law on Tax harmonisation and thus violated Art. 49 FedCst.

What is more interesting in the present context is the court's opinion on the second argument. The court found, in line with the plaintiffs' claims, that the cantonal law was also inconsistent with the general principles of tax law discussed above and that these are applicable not only to federal taxes but also to cantonal tax law. The judges dealt first with the meaning of these principles:

9.1 [... In the field of taxation, Art. 8 para. 1 of the Federal Constitution is implemented by the principles of universality and uniformity of taxation and by the principle of taxation according to economic 
power (Art. 127 para. 2 of the Federal Constitution [...]. These are tax principles which were originally derived from Article 4 of the Federal Constitution of 29 May 1874 and were then expressly incorporated into the Federal Constitution approved by the Swiss people and the cantons on 18 April 1999 [...].

9.2 The principle of general taxation requires that all persons and groups of persons be taxed in accordance with the same legal provision. It prohibits the exemption of certain persons or groups of persons from tax liability without objective reasons, since the financial burden on the Community of public tasks of a general nature must be borne by all citizens $[\ldots]$.

The principles of uniformity of taxation and of taxation according to economic strength require taxpayers in the same economic situation to bear a similar tax burden according to their ability to pay; in different circumstances, the tax burden must also take this into account. At the same time, the tax burden must be proportionate to the economic substrate available to the individual who, taking into account their personal situation and in proportion to their resources, has to contribute to covering public expenditure [...]

9.3 Art. 127 FedCst. is not contained in the chapter on fundamental rights (Art. 7 et seq. FedCst.), but in the chapter on the federal financial system (Art. 126 et seq. FedCst.). This rule therefore applies primarily to taxes levied by the Confederation. As already mentioned, however, the taxation principles contained therein are conceived and serve to concretise the principle of equal treatment (Art. 8 FedCst.), which as such permeates the entire Swiss legal system [...]. The cantonal legislature is therefore also bound by these provisions and must take them into account when regulating its tax system $[\ldots] .55$

The court, in a second step, applied these principles on the present case and concluded that the Ticino tax law was also inconsistent in this regard:

9.4 In the present case, Articles 3oge and 314e of the Income Tax Act aim to reduce by $70 \%$ the tax recovery rates for all exempt voluntary declarations made during a period of two years following their entry into force. These are clear violations of Articles 8(1) and 127(2) of the Constitution. 
Articles $309 \mathrm{e}$ and $314 \mathrm{e}$ of the Income Tax Act exempt self-incriminating persons from paying $70 \%$ of the taxes originally due and are therefore contrary to the principle of the generality of taxation, as they provide for a different and much more favourable treatment for those who have deducted taxes from the tax authorities than for those who, as taxpayers, do not belong to this category of persons.

At the same time, they are contrary to the principles of uniformity of taxation and taxation according to economic strength, according to which taxpayers in the same economic situation have to bear a similar tax burden depending on their ability to pay, and different circumstances have to be regarded differently from the point of view of the tax burden (previous consideration 9.2 with reference to case-law and doctrine).

Taxpayers who have correctly declared their taxable amounts and paid $100 \%$ of the amount due are treated differently to taxpayers who have not declared anything in the same case and who only declare their amounts in their self-declaration. The rules in question lead not only to a very different treatment of taxpayers with exactly the same economic power (violation of the so-called horizontal tax justice), but also to an unjustified unequal treatment of taxpayers with different economic power (violation of the so-called vertical tax justice). As the applications for interim measures have repeatedly pointed out, the application of Articles 309e and 314e LT also has consequences in this respect and, in particular, it cannot be excluded that - in view of the reduction introduced - taxpayers who have correctly declared their taxable amounts may have to pay even higher amounts compared to taxpayers who have failed to exist for higher taxable amounts and only do so when making their voluntary declaration. ${ }^{56}$

\section{Strengthening the Weak: Finance and Burden Equalisation}

\subsection{Unequal Financial Strength and Unequal Burdens as a Starting Point}

One of the downsides of the cantons' financial autonomy is that the financially weak cantons have to offset their unequal economic starting conditions with higher taxes, which in turn reduces their attractiveness for companies and

$56 \quad$ BGE 141 I 78 , Consid. 9.4. (translation by the author of this chapter). 
private individuals. On the other hand, the financially strong cantons become even more attractive, which allows them to further reduce their taxes.

A second element that affects the financial (and thus the tax) starting position of the different cantons is the unequal burdens that the different cantons have to bear:

These include, on the one hand, the geographical and topographical inequalities that lead to excessive burdens in certain cantons due to their location. Regions with an excessive burden in this sense are characterised by an above-average proportion of mountainous areas, dispersed settlement structures and low population density.

On the other hand, a specific population structure of a canton or its central functions can have a particular impact. This refers in particular to the core cities with large agglomerations (e.g. Zurich). These so-called sociodemographic specialties lead to disproportionate burdens for the affected cantons, while some other cantons benefit from their location in proximity to the affected cantons without carrying parts of the burden themselves (free-rider problem).

\subsection{Equalisation Mechanisms as a Means to Counter Those Inequalities}

This background led to the creation of Art. 135 FedCst. within the framework of the so-called New Financial Equalisation (NFA). The NFA formed an integral part of a very ambitious project to strengthen federalism and to unbundle tasks between the Confederation and the cantons. ${ }^{57}$ In its message to Parliament, the Federal Council described financial equalisation as follows:

Financial equalisation in the narrower sense between the cantons now distinguishes between equalisation of resources and equalisation of burdens. This makes the balance more targeted and effective. The balance between the resource-rich and the resource-weak cantons will be extended compared to the current system. In addition to the resource-rich cantons, the Confederation is now also contributing to their financing. It ensures that all cantons have sufficient resources. The current system, which is opaque and complicated - and transparent for only a few specialists - will be replaced by a transparent and comprehensible financial equilibrium. The federal parliament will be given the opportunity to set the parameters for equalisation of resources. This will make financial equalisation,

57 Biaggini, Kommentar zur Bundesverfassung, Art. 135 marginal no. 5; René Wiederkehr and August Mächler, “Commentary on Art. 135 FedCst.," in Die schweizerische Bundesverfassung, St. Galler Kommentar, eds. Bernhard Ehrenzeller et al. (Zurich, St. Gallen: Schulthess, 2014), marginal nos. $5 \mathrm{f}$. 
which is intended to reduce differences in the financial performance of the cantons, politically controllable. The resource index, which measures the financial performance of the cantons, cannot be manipulated in its concept and, in contrast to the current financial strength index, deliberately refrains from taking burden elements into account. In future, for example, the cantonal tax burden will no longer be used as a criterion for measuring the financial performance of a canton, but will instead be limited to the tax or resource potential of a canton that can be exhausted from a fiscal point of view. In this way, misguided incentives and conflicting objectives are to be avoided in future. The Confederation is to compensate the cantons for excessive and uninfluenceable burdens arising from geographical and topographical conditions or their specific population structure by means of a corresponding equalisation of burdens. This compensation will also be determined to its extent by the federal parliament and is therefore politically controllable. ${ }^{58}$

In 2004, vertical fiscal equalisation was put on a new constitutional basis, supplemented by horizontal equalisation between the cantons. The constitutional provision reads as follows:

Art. 135 FedCst. Equalisation of financial resources and burdens

1 The Confederation shall issue regulations on the equitable equalisation of financial resources and burdens between the Confederation and the Cantons as well as among the Cantons.

2 The equalisation of financial resources and burdens is intended in particular to:

a. reduce the differences in financial capacity among the Cantons;

b. guarantee the Cantons a minimum level of financial resources;

c. compensate for excessive financial burdens on individual Cantons due to geo-topographical or socio-demographic factors;

d. encourage inter-cantonal cooperation on burden equalisation;

e. maintain the tax competitiveness of the Cantons by national and international comparison.

3 The funds for the equalisation of financial resources shall be provided by those Cantons with a higher level of resources and by the Confederation. The payments made by those Cantons with a higher

$5^{8}$ Message of the Federal Council, $\mathrm{BBl} 2002,2294$ et seq. (translation by the author of this chapter); see also Hänni, "Commentary on Art. 135 FedCst.," marginal nos. 88 et seq. 
level of resources shall amount to a minimum of two thirds and a maximum of 8 o per cent of the payments made by the Confederation.

\subsection{The Provision (Regulating Equalisation Mechanisms) in Detail} 6.3.1 Legislative Mandate (para. 1)

Art. 135 para. 1 FedCst. mandates the Confederation to issue regulations on appropriate financial resources and burden equalisation between the Confederation and the cantons and between the cantons. Financial equalisation (in a narrow sense) means 'all financial transfers which serve the redistribution of resources between the cantons and the equalisation of excessive structural burdens'; 59 whereas financial equalisation in the broader sense also includes transfers between the Confederation and the cantons which are related to the distribution of tasks and revenues. ${ }^{60}$ The notion of load balancing was only introduced during parliamentary deliberations and is intended to distinguish the second branch of the financial equalisation mechanism, namely the equalisation of burdens, from the first branch of the financial equalisation mechanism, the equalisation of financial resources, a distinction which is also reflected in the terminology of the federal law on the financial and resource equalisation that resulted from the legislative mandate codified in Art. 135 para. 1 FedCst. ${ }^{61}$

A distinction must be made between vertical and horizontal financial equalisation. Transfer payments by the Confederation to the cantons are referred to as vertical equalisation, whereas those between the cantons fall under horizontal equalisation. ${ }^{62}$ This is expressed in the wording of paragraph 1 'between the Confederation and the cantons' or 'between the cantons'. The legislative competence of the Confederation encompasses both forms. ${ }^{63}$ However, the constitutional provision does not affect intra-cantonal finance and burden sharing. ${ }^{64}$ Nevertheless, the federal state's equalisation has not remained

59 Message of the Federal Council, BBl 20022543 (translation by the author of this chapter).

6o Biaggini, Kommentar zur Bundesverfassung, Art. 135 marginal no. 7; Hänni, "Commentary on Art. 135 FedCst.," marginal no. 13.

61 Hänni, "Commentary on Art. 135 FedCst.," marginal no. 13.

62 Jean-François Aubert, "Commentary on Art. 135 FedCst.," in Petit Commentaire de la Constitution fédérale de la Confédération suisse, eds. Jean-François Aubert and Pascal Mahon (Zurich, Basel, Geneva: Schulthess, 2003), marginal no. 4; Biaggini, Kommentar zur Bundesverfassung, Art. 135 marginal no. 8; Hänni, "Commentary on Art. 135 FedCst.," marginal no. 14; Wiederkehr and Mächler, "Commentary on Art. 135 FedCst.," marginal no. 13 .

63 Biaggini, Kommentar zur Bundesverfassung, Art. 135 marginal no. 8.

64 Biaggini, Kommentar zur Bundesverfassung, Art. 135 marginal no. 8; Hänni, "Commentary on Art. 135 FedCst.," marginal no. 14. 
without consequences for the inner-cantonal level. ${ }^{65}$ Indeed, the cantons have almost entirely reorganised their inner-cantonal equalisation systems between the communes at the same time as (or shortly after) the entry into force of the NFA. ${ }^{66}$ This development is worth mentioning, since the federal government must take into account the possible effects on the municipalities when carrying out its legislative mandate according to Art. 50 para. 2 of the Federal Constitution. ${ }^{67}$

Concerning the scope of the federal competence, Art. 135 para. 1 FedCst. obliges the Confederation to issue regulations on appropriate vertical and horizontal financial and burden balancing. The new constitutional provision drawn up within the framework of the NFA thus differs significantly from its predecessor, which only explicitly mentioned a federal power to promote horizontal equalisation. With regard to vertical financial equalisation, the federal competence is exclusive; the cantons therefore would have no authority to oblige the Confederation to make transfer payments, even if the federal legislature failed to act. As far as horizontal financial equalisation is concerned, there is scope for cantonal regulations insofar as the implementing legislation of the Confederation does not contain conclusive provisions. However, the remaining cantonal regulations are likely to be of a more theoretical nature, with cantonal regulations in the area of horizontal inter-cantonal burden sharing most likely to be considered. 68

The addressee of the constitutional obligation to enact regulations is the Confederation; the cantons are not addressed. ${ }^{69}$ The constitutional provision does not prescribe any specific method for the legislator to achieve the objectives of financial and burden equalisation. ${ }^{70}$ This means that the legislator has considerable room for manoeuvre. However, there can be no doubt that fiscal equalisation should (henceforth) be clearly distinguished from federal subsidies. ${ }^{71}$ The constitutional text does not explicitly exclude this link, but the declarations of the different organs involved in the elaboration of the NFA are

\footnotetext{
65 Biaggini, Kommentar zur Bundesverfassung, Art. 135 marginal no. 8.

66 Hänni, "Commentary on Art. 135 FedCst.," marginal no. 14.

67 See also: Biaggini, Kommentar zur Bundesverfassung, Art. 135 marginal no. 8.

68 For the whole paragraph see: Biaggini, Kommentar zur Bundesverfassung, Art. 135 marginal no. 9; Hänni, "Commentary on Art. 135 FedCst.," marginal no. 15.

69 Biaggini, Kommentar zur Bundesverfassung, Art. 135 marginal no. 10; Hänni, "Commentary on Art. 135 FedCst.", marginal no. 16.

70 Biaggini, Kommentar zur Bundesverfassung, Art. 135 marginal no. 10; Hänni, "Commentary on Art. 135 FedCst.", marginal no. 16.

71 Biaggini, Kommentar zur Bundesverfassung, Art. 135 marginal no. 10; Hänni, “Commentary on Art. 135 FedCst.," marginal no. 16.
} 
clear in this respect, ${ }^{72}$ as one of the main objectives of the entire NFA reform project is to decouple federal subsidies from fiscal equalisation. Federal legislation has, moreover, been based on this implicit requirement, in that both the means for equalising resources and burdens are directed without any commitment to a specific purpose. ${ }^{73}$

Substantive limits are set to the Confederation in the fulfilment of its legislative mandate by the principle of proportionality: the equalisation of finances and burdens should be 'appropriate'. This indeterminate legal concept is intended to serve the legislature as a guideline for the implementation of the constitutional mandate: on the one hand, a merely symbolic legislation without recognisable and noticeable effects would not be compatible with the constitutional provision (lower minimum). On the other hand, the limits of solidarity must not be overstretched. What is needed are political decisions with a sense of proportion which, in particular, do not call into question the willingness of the resource-rich cantons to perform within the framework of horizontal financial equalisation. Further substantive provisions on the structure of financial equalisation and burden sharing are contained in paragraphs 2 and 3 of Art. 135 of the Federal Constitution. ${ }^{74}$

The Confederation has fulfilled its legislative mandate by enacting the Federal Law on the Equalisation of Finances and Burdens (FiLaG). The funds to be made available by the Confederation and (resource-rich) cantons for the equalisation of resources are determined by the Federal Assembly in a federal decree requiring a referendum for a period of four years (Art. 5 para. 1 FiLaG). The same applies to the basic contribution for geographical-topographical and sociodemographic burden sharing (Art. 9 para. 1 FiLaG). In the interest of transparency, both basic contributions are determined separately. Furthermore, the law expressly states that the funds are to be allocated to the cantons without earmarking. ${ }^{75}$ The gradation of the federal subsidies on the basis of the so-called financial strength index, which was practised in the former financial equalisation system, became obsolete with the implementation of the legislative mandate of Art. 135 para. 1 of the Federal Constitution; ${ }^{76}$ this also applies to the cantons' shares of federal revenue and of the Swiss National

72 Message of the Federal Council, BBl 20022291 et seq.

73 Hänni, “Commentary on Art. 135 FedCst.," marginal no. 16.

74 For this paragraph, see: Biaggini, Kommentar zur Bundesverfassung, Art. 135 marginal no. 11; Hänni, "Commentary on Art. 135 FedCst.," marginal no. 17.

75 Art. 6 para. 2 FiLaG and Art. 9 para. 4 FiLaG.

76 Biaggini, Kommentar zur Bundesverfassung, Art. 135 marginal no. 10. 
Bank's profits. In a broader sense, the latter two federal transfers nevertheless have a certain compensatory effect. ${ }^{77}$

\subsubsection{Objectives (para. 2)}

Paragraph 2 lists five objectives of financial and burden equalisation, which have the effect of limiting the scope of the legislator. ${ }^{78}$ In fact, it is hardly conceivable that the legislator could strive for further targets in addition to these relatively broad objectives, although the constitutional text would suggest this possibility by using the addition 'in particular. 79

Letter a deals with the first aim of financial and burden sharing, which is to reduce the differences in financial performance between the cantons. The aim is to reduce differences, but not to achieve full equality. ${ }^{80}$ When determining financial performance, the so-called resource potential is the decisive criterion. ${ }^{81}$ Resource potential is to be understood as the value of the resources of the canton concerned that can be exhausted from a fiscal point of view and not the actual tax revenues or the tax burdens. ${ }^{82}$ The concrete determination of the resource potential is based on the taxable income and assets of natural persons and the taxable profits of legal entities. ${ }^{83}$ The resource potential is determined annually by the Federal Council together with the cantons for each canton per capita of its inhabitants; the figures for the last three available years are decisive (Art. 3 para. 4 FiLaG). Art. 3 para. 5 FiLaG stipulates that cantons whose resource potential per capita is above the Swiss average $(=100)$ are considered to have a strong resource base, while cantons whose potential per capita is below the average are considered to have a weak resource base.

These seemingly very technical regulations for the calculation of resource potentials have a significant influence on the question of the financing of

77 For this paragraph, see: Biaggini, Kommentar zur Bundesverfassung, Art. 135 marginal no. 12; Hänni, "Commentary on Art. 135 FedCst.," marginal no. 18.

78 Hänni, "Commentary on Art. 135 FedCst.," marginal no. 19.

79 Hänni, "Commentary on Art. 135 FedCst.," marginal no. 20.

8o Biaggini, Kommentar zur Bundesverfassung, Art. 135 marginal no. 14; Hänni, "Commentary on Art. 135 FedCst.," marginal no. 20; Wiederkehr and Mächler, "Commentary on Art. 135 FedCst.," marginal no. 22.

81 Art. 3 et seq. FiLaG; see also: Biaggini, Kommentar zur Bundesverfassung, Art. 135 marginal no. 14; Hänni, "Commentary on Art. 135 FedCst.," marginal no. 20.

82 Art. 3 para. 1 FiLaG; see also: Biaggini, Kommentar zur Bundesverfassung, Art. 135 marginal no. 14; Hänni, "Commentary on Art. 135 FedCst.," marginal no. 20.

83 Art. 3 et seq. FiLaG; Art. 1 FiLaV; see also: Biaggini, Kommentar zur Bundesverfassung, Art. 135 marginal no. 14; Hänni, “Commentary on Art. 135 FedCst.," marginal no. 20; Wiederkehr and Mächler, "Commentary on Art. 135 FedCst.," marginal no. 22. 
resource compensation and on the determination of the recipient cantons: Art. 135 para. 3 FedCst. makes it clear that resource-rich cantons and the Confederation must provide the resources for resource compensation in favour of resource-weak cantons. ${ }^{84}$ As explained above, the amount to be spent on resource equalisation is determined every four years by the Federal Assembly in a federal decree subject to mandatory referendum.

Letter $b$ provides a further aim of financial and burden sharing i.e. to guarantee the cantons' minimum financial resources. ${ }^{85}$ This is intended to enable the cantons to fulfil their tasks independently and at the same time to have a certain degree of freedom of choice. ${ }^{86}$ Autonomy and personal responsibility become empty promises when a canton has to continuously fight for financial survival for structural reasons, without any prospect of improvement. ${ }^{87}$ The open concept of 'minimal financial resources' must be concretised by the legislator and is closely related to letter $a$, where the reduction of differences in financial performance is addressed. Even the weakest cantons should have at their disposal a minimum of financial resources through resource equalisation. ${ }^{88}$ The Federal Assembly has set this lower minimum at $85 \%$ of the Swiss average in financial resources (Art. 6 para. 3 FiLaG). This requirement is met if the canton's own relevant resources, together with the services it receives from the resource equalisation scheme, reach the desired minimum. ${ }^{89}$ At the same time, the equalisation of resources may not change the ranking of the cantons, which means that there is also an (indirect) upper limit of equalisation of resources. ${ }^{90}$ The distribution of resources among the resource-weak cantons is carried out by the Federal Council and is redefined annually, with the particularly resource-weak cantons receiving

84 Art. 4 para. 1 FiLaG and Art. 6 para. 1 FiLaG; see also: Biaggini, Kommentar zur Bundesverfassung, Art. 135 marginal no. 14; Hänni, "Commentary on Art. 135 FedCst.," marginal no. 21.

85 The entire system was recently evaluated and is currently being revised based on experience gained. The aim of the planned adjustment is to relieve the financial burden on the strong cantons, but the total amount of funds invested in financial equalisation should remain the same. See: https://www.efv.admin.ch/efv/de/home/aktuell/nsb-news_list. msg-id-72354.html, last updated on 28 september 2018, accessed on 20 november 2018.

86 Hänni, "Commentary on Art. 135 FedCst.," marginal no. 22.

87 Hänni, "Commentary on Art. 135 FedCst.," marginal no. 22.

88 Biaggini, Kommentar zur Bundesverfassung, Art. 135 marginal no. 15; Hänni, “Commentary on Art. 135 FedCst.," marginal no. 22.

89 Art. 6 para. 3 FiLaG; see also: Hänni, "Commentary on Art. 135 FedCst.," marginal no. 22.

$90 \quad$ Art. 6 para. 1 sentence 3 FiLaG; see also: Biaggini, Kommentar zur Bundesverfassung, Art. 135 marginal no. 15; Hänni, "Commentary on Art. 135 FedCst.," marginal no. 22. 
above-average benefits in the sense of the objective set out in Art. 135 para. 2 lit. b FedCst.

The so-called geographic-topographic and sociodemographic burden sharing is provided in letter $c$. Indeed, in addition to resource equalisation and strictly separate from it, the NFA reform project created a second equalisation vessel aimed at granting cantons compensation payments for excessive burdens. This second instrument of financial equalisation consists of a burden sharing scheme financed by the Confederation. ${ }^{91}$ The compensation is not complete, but only partial and does take into account special burdens, most of which however cannot be changed. ${ }^{92}$

On the one hand, cantons under Art. 7 FiLaG are entitled to burden sharing if they are overburdened by their geographical and topographical situation. Indications for such excessive burdens are, in particular, an above-average proportion of high-lying settlement and productive areas as well as disperse settlement structures and a low population density (Art. 7 para. 2 FiLaG). The excessive burden results from the altitude (e.g. higher costs for winter road clearance, maintenance costs for infrastructure, etc.), from burdens resulting from the steepness of the terrain (forest management, avalanche barriers, etc.), and from the sparsity of the population (e.g. compulsory schooling, sewage supply, health care). ${ }^{93}$ The special burdens of these three categories can be measured by sub-indicators such as the median altitude of the productive area, the proportion of inhabitants with a residential altitude of over 800 metres above sea level or the proportion of inhabitants in settlements with less than 200 inhabitants, which can be used to make plausible statements about the extent of these special burdens. ${ }^{94}$

On the other hand, cantons that are exposed to particular burdens due to socio-demographic conditions are entitled to burden sharing. ${ }^{95}$ These sociodemographic burdens are special burdens that can be traced back to the population structure of a canton or to the importance of a certain canton due to its function as a socio-economic and infrastructural centre. ${ }^{96}$

\footnotetext{
$91 \quad$ Art. 7 et seq. FiLaG; see also: Hänni, "Commentary on Art. 135 FedCst.," marginal no. 23; Wiederkehr and Mächler, "Commentary on Art. 135 FedCst.," marginal no. 25.

92 Biaggini, Kommentar zur Bundesverfassung, Art. 135 marginal no. 16; Hänni, "Commentary on Art. 135 FedCst.," marginal no. 23.

93 Hänni, "Commentary on Art. 135 FedCst.," marginal no. 24.

94 Art. 29 et seq. FiLaV (the FiLaV being the decree concretising certain provisions of the FiLaG).

95 Art. 7 et seq. FiLaG.

96 Biaggini, Kommentar zur Bundesverfassung, Art. 135 marginal no. 16; Hänni, "Commentary on Art. 135 FedCst.," marginal no. 25.
} 
Such a situation, for which the abbreviation A-city problem is often used, is characterised by the fact that the core cities typically have an aboveaverage proportion of older and poor people, single people, single parents, dependent people, trainees, unemployed people, outsiders and foreigners in their population structure..$^{97}$ What these A-groups have in common is that they cause relatively high burdens while at the same time generating little tax revenue. Not to be equated with sociodemographic burdens are the external effects associated with centre services, so-called spillovers. ${ }^{98}$ In this context, spillovers are negative effects that occur when services provided by a canton or a city can also be claimed by residents of other local authorities without the latter being (financially) responsible for the services consumed (by their residents). ${ }^{99}$ Centre services with spillover effects can be found, for example, in the areas of transport, health and culture. Such centre services are to be compensated by the inter-cantonal equalisation of burdens. ${ }^{100}$

As in the case of equalisation of resources, the Federal Assembly, in a federal decree subject to a referendum, determines a basic contribution for each of the four years for geographical-topographic and sociodemographic equalisation of burdens (Art. 9 para. 1 FiLaG). It is also obliged to take into account the results of the effectiveness report pursuant to Art. 18 FiLaG. The funds allocated to the cantons under this heading are not earmarked (Art. 9 para. 4 FiLaG). Unlike resource equalisation, burden equalisation is financed entirely by the Confederation. ${ }^{101}$

A further objective of financial and burden sharing is to use inter-cantonal burden sharing to compensate for services received by residents of one canton in another canton without paying the full cost (letter d). This provision is intended to prevent spillover effects and free-riding behaviour. ${ }^{102}$ It should lead to public services being provided to an optimum extent and to a fair distribution of burdens based on actual usufruct. ${ }^{103}$ Closely linked to the first

\footnotetext{
97 Biaggini, Kommentar zur Bundesverfassung, Art. 135 marginal no. 16; Hänni, "Commentary on Art. 135 FedCst.", marginal no. 25.

98 Hänni, "Commentary on Art. 135 FedCst.," marginal no. 25.

99 Hänni, "Commentary on Art. 135 FedCst.," marginal no. 25; Wiederkehr and Mächler, "Commentary on Art. 135 FedCst.," marginal no. 11.

100 Hänni, "Commentary on Art. 135 FedCst.," marginal no. 25; Wiederkehr and Mächler, "Commentary on Art. 135 FedCst.," marginal no. 11.

101 Biaggini, Kommentar zur Bundesverfassung, Art. 135 marginal no. 16.

102 Hänni, "Commentary on Art. 135 FedCst.," marginal no. 27.

103 Hänni, "Commentary on Art. 135 FedCst.," marginal no. 27.
} 
objective is the intended improvement of efficiency due to the exploitation of economies of scale. ${ }^{104}$ In this way, a significant advantage of an area reform is exploited without having to accept its disadvantages. In addition, intensified inter-cantonal cooperation should have a preventive effect against excessive centralisation. ${ }^{105}$ Indeed, cross-cantonal tasks can be performed in a meaningful way without being transferred to the federal level. A typical example is the financial compensation of so-called 'centre services' (e.g. in the areas of transport, health and culture). ${ }^{106}$

The classic instrument for achieving these objectives is the inter-cantonal treaty (Art. 48 FedCst.). ${ }^{107}$ The federal government's financial resource and burden equalisation must be structured and the legislative competence according to para. 1 exercised in such a way that inter-cantonal cooperation is promoted with regards to burden equalisation. ${ }^{108}$ Art. 135 FedCst. does not comment on the instruments. At the legislative level, the Confederation obliges the cantons to draw up an inter-cantonal framework agreement in which the principles and certain modalities of inter-cantonal cooperation are laid down (Art. 13 FiLaG). This inter-cantonal framework agreement will then form the basis for the negotiation of specific cooperation agreements, which will thus be noticeably facilitated. ${ }^{109}$ Such a framework agreement was drawn up under the auspices of the Conference of Cantonal Governments. ${ }^{110}$ Art. 48a of the Federal Constitution then provides for instruments which, under certain conditions, make it possible to force unwilling cantons to cooperate horizontally in certain areas of responsibility. ${ }^{111}$ These instruments go well beyond the promotion objective enshrined in Art. 135 para. 2 lit. d of the Federal Constitution but are

\footnotetext{
104 Hänni, "Commentary on Art. 135 FedCst.," marginal no. 27.

105 Message of the Federal Council, BBl 2002 2352; Hänni, "Commentary on Art. 135 FedCst.," marginal no. 27 .

106 Biaggini, Kommentar zur Bundesverfassung, Art. 135 marginal no. 17; Hänni, “Commentary on Art. 135 FedCst.", marginal no. 27.

107 Biaggini, Kommentar zur Bundesverfassung, Art. 135 marginal no. 17.

108 Biaggini, Kommentar zur Bundesverfassung, Art. 135 marginal no. 17; Hänni, "Commentary on Art. 135 FedCst.", marginal no. 28.

109 Biaggini, Kommentar zur Bundesverfassung, Art. 135 marginal no. 17; Hänni, “Commentary on Art. 135 FedCst.," marginal no. 28.

110 See for more information and a link to the framework agreement: https://kdk.ch/de/ themen/nfa-und-interkantonale-zusammenarbeit/interkantonale-zusammenarbeit-mitlastenausgleich/, accessed on 29 November 2018.

111 See also Art. 10 FiLaG, which explicitly refers to Art. 48a FedCst; Biaggini, Kommentar zur Bundesverfassung, Art. 135 marginal no. 17.
} 
likely to be covered by Art. 48a of the Federal Constitution as a constitutional basis. ${ }^{112}$

The fifth and last of the objectives explicitly mentioned in Article 135 para. 2 of the Federal Constitution (lit. e) is intended to ensure that the balancing of financial resources and burdens preserves the tax competitiveness of the cantons in national and international relations. While the first four objectives have been given clearer contours by the legislator in the FiLaG, specific provisions on tax competitiveness have been sought in vain. ${ }^{113}$ On the one hand, it could be argued that the tax competitiveness of the resource-weak cantons is supported and promoted by the equalisation of resources. ${ }^{114} \mathrm{On}$ the other hand, the target could be seen as an unspecified limit to financial and burden equalisation that would allow resource-rich cantons to (continue to) pursue a low tax policy. ${ }^{115}$ At the same time, the goal is that financial resources and burden sharing would not prevent resource-weak cantons from participating in inter-cantonal and international tax competition. ${ }^{116}$ The provision, which only found its way into the constitution in the debates of the Councils (i.e. the National Council and the Council of the Cantons), ${ }^{117}$ also has a referendum-political dimension in that there are fears that financial and burden balancing could ultimately lead to (undesirable) material tax harmonisation. ${ }^{118}$

\subsubsection{Financing the Equalisation of Resources (para. 3)}

The financing of the equalisation of resources is regulated in para. 3. The political significance of this issue justifies standardisation at constitutional level. ${ }^{119}$ In contrast, the financing of burden sharing, which is borne solely

112 Biaggini, Kommentar zur Bundesverfassung, Art. 135 marginal no. 17; Hänni, "Commentary on Art. 135 FedCst.," marginal no. 28; Wiederkehr and Mächler, "Commentary on Art. 135 FedCst.," marginal no. 26.

113 Biaggini, Kommentar zur Bundesverfassung, Art. 135 marginal no. 18.

114 Hänni, "Commentary on Art. 135 FedCst.," marginal no. 29.

115 Hänni, "Commentary on Art. 135 FedCst.," marginal no. 29; Wiederkehr and Mächler, "Commentary on Art. 135 FedCst.," marginal no. 28.

116 Hänni, "Commentary on Art. 135 FedCst.," marginal no. 29; Wiederkehr and Mächler, "Commentary on Art. 135 FedCst.," marginal no. 28.

117 Wiederkehr and Mächler, "Commentary on Art. 135 FedCst.," marginal no. 28.

118 Biaggini, Kommentar zur Bundesverfassung, Art. 135 marginal no. 18; Hänni, "Commentary on Art. 135 FedCst.," marginal no. 29.

119 Biaggini, Kommentar zur Bundesverfassung, Art. 135 marginal no. 2o; Hänni, "Commentary on Art. 135 FedCst.", marginal no. 3 o. 
by the Confederation, appears less sensitive, which is why it is only regulated at the legislative level. ${ }^{120}$ Paragraph 3 anchors the principle that the federal government and the resource-rich cantons are responsible for equalising resources (vertical and horizontal equalisation). ${ }^{121}$ The share to be paid by the resource-rich cantons depends on the funds made available by the Confederation. In this respect, the constitutional legislator has set a lower minimum (two-thirds of the federal contribution) and an upper maximum ( $80 \%$ of the federal contribution) for the cantonal share. ${ }^{122}$ Since these limits do not yet say anything about the absolute amount of the funds made available by the Confederation, the protection of the resource-rich cantons is also provided by para. 1 ('appropriate' financial and burden equalisation) on the one hand and by lit. b of para. 2, according to which the financial equalisation in favour of the resource-weak cantons should only lead to a minimum endowment, on the other hand. ${ }^{123}$ Should the resource-rich cantons be overused by the federal legislature despite these protection mechanisms, they would have to defend themselves against this 'exploitation' using political means. ${ }^{124}$

\subsubsection{Compensation for Hardship}

The transition to the NFA brought about considerable changes in financial flows both between the Confederation and the cantons and between the cantons. As a result of these changes, some resource-weak cantons, which benefited from the former equalisation system, now receive less financial compensation. For some of these cantons, the losses represented a major burden, especially since their income and expenditure structures had adapted strongly to the then existing equalisation system in recent decades. ${ }^{125}$

Without being obliged to do so by Article 135 of the Federal Constitution, the Federal legislator decided to give the cantons time to adapt their public finance structure to the NFA by means of a hardship

\footnotetext{
120 Biaggini, Kommentar zur Bundesverfassung, Art. 135 marginal no. 20; Hänni, "Commentary on Art. 135 FedCst.," marginal no. 3 o.

121 Biaggini, Kommentar zur Bundesverfassung, Art. 135 marginal no. 21.

122 Art. 135 para. 3 sentence 2 FedCst.

123 Biaggini, Kommentar zur Bundesverfassung, Art. 135 marginal no. 21; Hänni, "Commentary on Art. 135 FedCst.," marginal no. 3 o.

124 Hänni, "Commentary on Art. 135 FedCst.," marginal no. 3 o.

125 For the whole paragraph, see: Hänni, "Commentary on Art. 135 FedCst.," marginal no. 31; see also: Biaggini, Kommentar zur Bundesverfassung, Art. 135 marginal no. 19.
} 
adjustment. ${ }^{126}$ Article 19 of the FiLaG thus provides for a temporary hardship adjustment, the contributions of which are intended to cushion the transition from the old to the new system. Pursuant to Article 19 para. 3 FiLaG, the Federal Assembly shall determine the initial amount of the hardship adjustment in a federal decree requiring a referendum. According to the 2004/ o5 global balance sheet, CHF 430 million per year must be made available for the hardship adjustment. Two-thirds of the hardship compensation is financed by the Confederation and one third by the cantons (Art. 19 para. 2 FiLaG). The hardship compensation is conceived as a temporary transitional aid and is therefore not an integral part of the new compensation system. ${ }^{127}$ It therefore also breaks through the limitations of budget neutrality in the transition to the NFA, ${ }^{128}$ the former creating a close link between the unbundling of tasks, the abolition of the previous financial equalisation and the new equalisation system. ${ }^{129}$

The total annual volume of the hardship adjustment is definitively determined in a federal decree and stays in place for eight years. ${ }^{130}$ Thereafter, this amount is reduced annually by $5 \%$ of the initial amount. The basis for determining the initial amount is the 2004/05 global balance sheet. Every four years, the Federal Assembly can decide, on the basis of the effectiveness report, whether the hardship adjustment should be abolished in whole or in part. Contributions within the framework of the hardship adjustment are paid for a maximum of 28 years. ${ }^{131}$

\section{$7 \quad$ Rules and Methods for Equalisation of Financial Resources - The Mechanism of Implementation}

The technical implementation, which was decided by the Confederation together with the cantons, has been agreed on as a multi-stage procedure.

126 Biaggini, Kommentar zur Bundesverfassung, Art. 135 marginal no. 19; Hänni, "Commentary on Art. 135 FedCst.," marginal no. 32; Wiederkehr and Mächler, "Commentary on Art. 135 FedCst.," marginal no. 12.

127 Hänni, "Commentary on Art. 135 FedCst.," marginal no. 32; Wiederkehr and Mächler, "Commentary on Art. 135 FedCst.," marginal no. 12.

128 Biaggini, Kommentar zur Bundesverfassung, Art. 135 marginal no. 19.

129 Hänni, "Commentary on Art. 135 FedCst.," marginal no. 32.

130 Hänni, "Commentary on Art. 135 FedCst.," marginal no. 33.

131 Wiederkehr and Mächler, "Commentary on Art. 135 FedCst.," marginal no. 12; for the whole paragraph see: Biaggini, Kommentar zur Bundesverfassung, Art. 135 marginal no. 19; Hänni, "Commentary on Art. 135 FedCst.," marginal no. 33. 


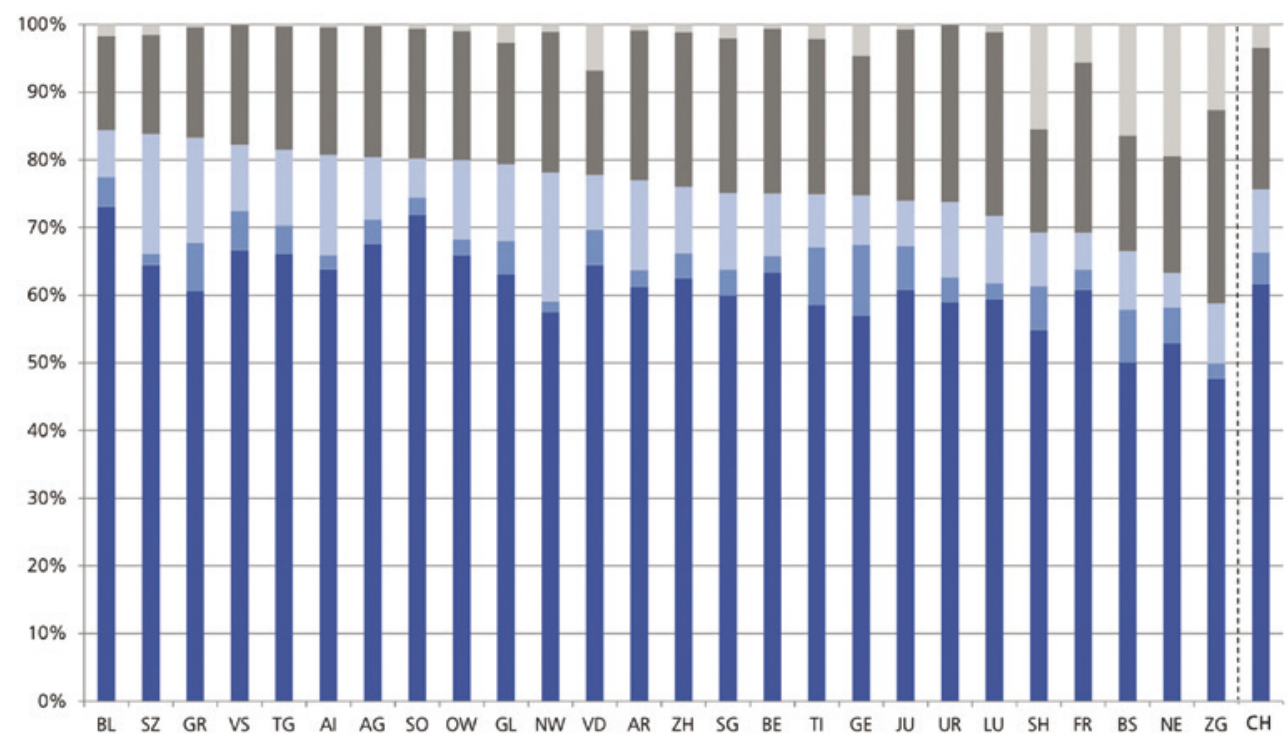

Profits of firms with special fiscal status

Taxable assets of individual taxpayers

Taxable revenues of individual taxpayers

FIGURE 9.3 Different elements of the resource potential of the cantons in 2019 SOURCE: FEDERAL FINANCE ADMINISTRATION

Firstly, the taxable income of individual taxpayers in the cantons must be determined. In a second step, income from taxpayers' taxable assets in the cantons is added. In a third step, the taxable profits of companies are included, as shown in Figure 9.3.

This data can then be used to determine the standardised tax revenue per capita in each canton. On this basis, the cantonal average and $85 \%$ of this average can be determined.

The fifth and final step ensures that all cantons reach at least $85 \%$ (guaranteed minimum financing) of the cantonal average through resource equalisation, as shown in Figure 9.4.

The graph shows that resources are allocated from the resource-rich cantons to the resource-weak cantons so that after the equalisation, all the cantons dispose of at least $85 \%$ of the Swiss average in resources.

The final practical results of the vertical and horizontal flows of resources and burden equalisation is as shown in Figure 9.5 (in million CHF). 


\section{Resource index 2020 before and after equalization}

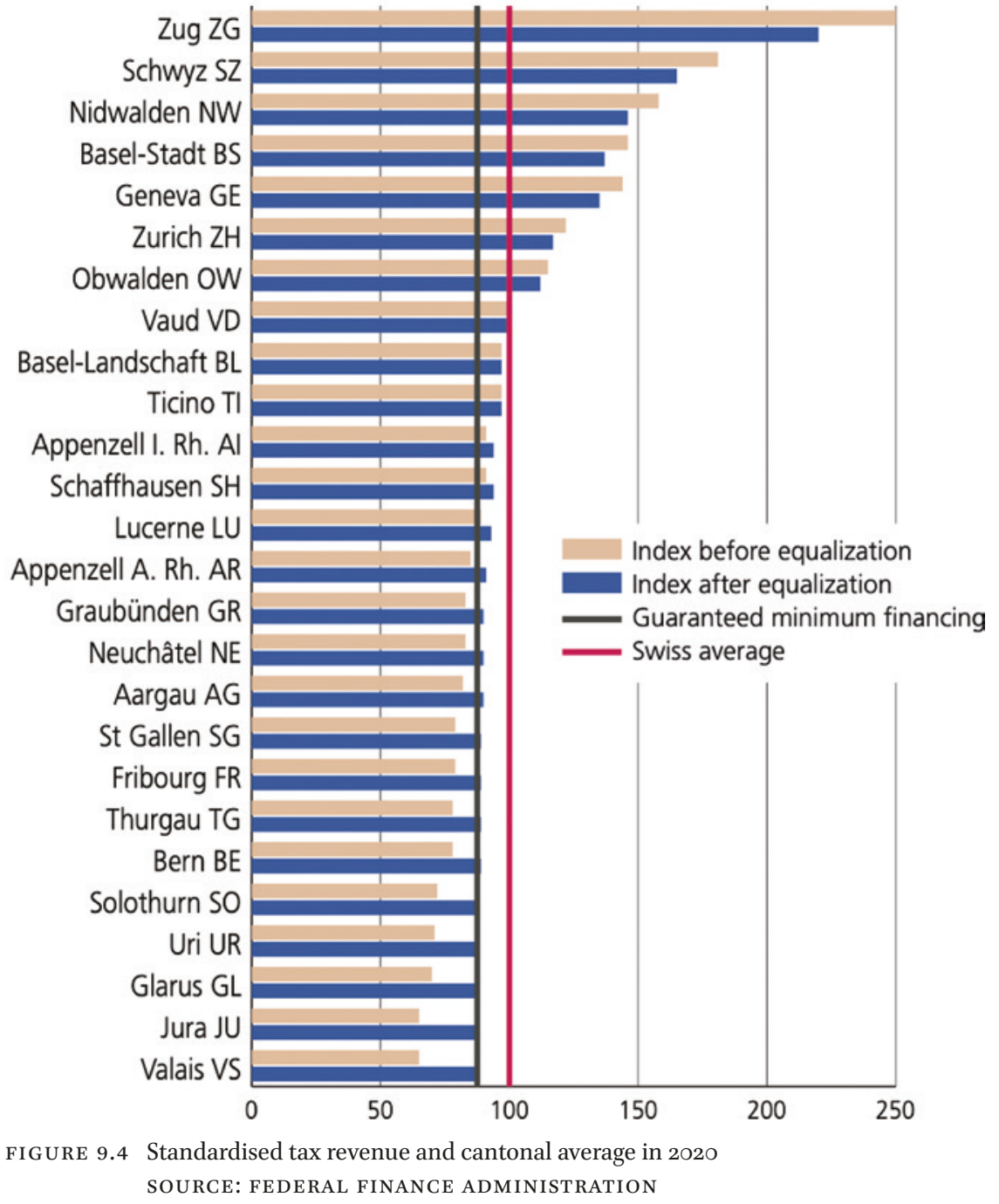

Figure 9.6 shows the equalisation for 2019 .

This graph shows that in the richest cantons, each taxpayer contributes (an average of) 2,727 CHF of his taxes to resource-weak cantons whereas in resource-weak cantons, taxpayers each receive (an average of) 2,288 C HF coming from the equalisation mechanism. 


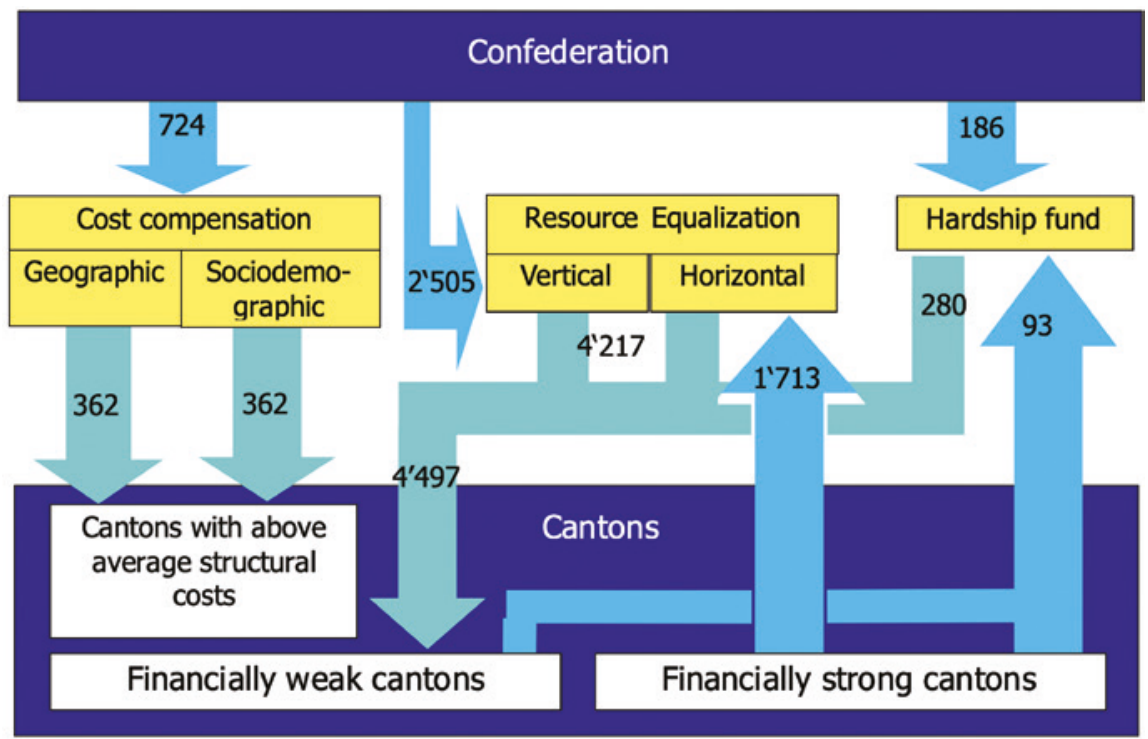

FIGURE 9.5 Schema of the final result of the Swiss financial resources and burden equalisation 2019

SOURCE: FEDERAL FINANCE ADMINISTRATION

The Swiss Tax System is an illustration of the tension that exists between diversity and equality in a federal State. The Federal Constitution grants the cantons (and indirectly the communes) considerable autonomy in levying direct taxes on the income and assets of natural and legal persons. Autonomy leads to significant differences in the tax burden, depending on the canton. These differences are first of all mitigated by the vertical and horizontal financial compensation attributed according to the equalisation mechanism. Furthermore, the formal tax harmonisation makes the various cantonal tax systems at least comparable. It has to be mentioned that to date, all proposals for material tax harmonisation ${ }^{132}$ have been rejected. ${ }^{133}$ Finally, individual taxpayers are

132 Material tax harmonisation as in the substance of tax law being harmonised, not only formal, procedural elements of it.

133 The most recent propositions being the federal initiative 'Steuergerechtigkeits-Initiative', rejected by the Swiss voters (see BBl 20112772 ) and the parliamentary motion 15.3113 introduced by Barbara Gysi, member of the Swiss National Council (one of the chambers of the Swiss Parliament) (see AB 2017 NR 25 f.). 


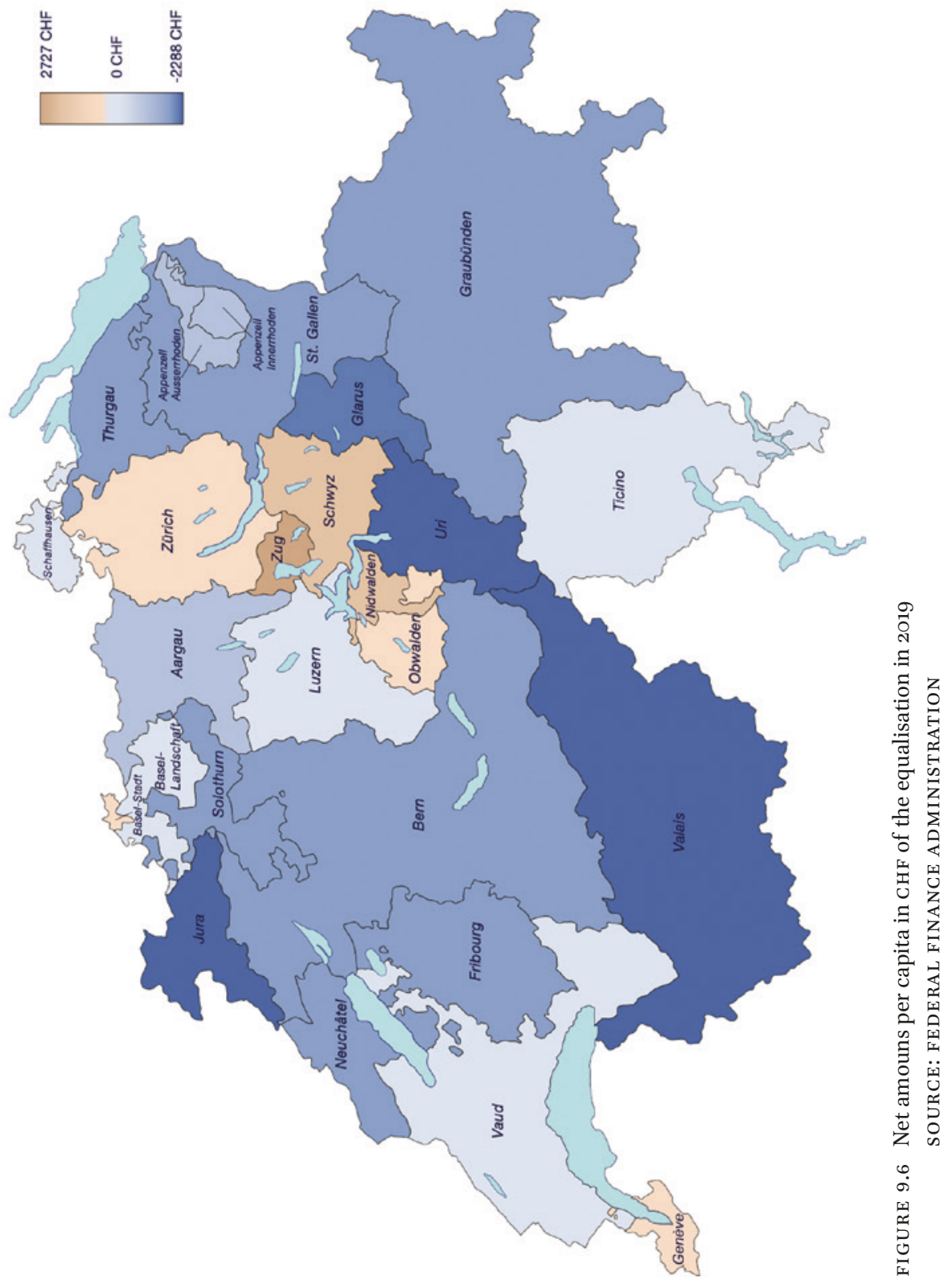


protected against arbitrary discrimination due to differences in tax burdens by certain constitutional, legally enforceable minimal guarantees, which constitute the concretisation of the general right to equal treatment.

\section{Bibliography}

Aubert, Jean-François. "Commentary on Art. 127 FedCst." In Petit Commentaire de la Constitution fédérale de la Confédération suisse, edited by Jean-François Aubert and Pascal Mahon, 1008-1015. Zurich, Basel, Geneva: Schulthess, 2003.

Aubert, Jean-François. "Commentary on Art. 128 FedCst." In Petit Commentaire de la Constitution fédérale de la Confédération suisse, edited by Jean-François Aubert and Pascal Mahon, 1016-1022. Zurich, Basel, Geneva: Schulthess, 2003.

Aubert, Jean-François. "Commentary on Art. 129 FedCst." In Petit Commentaire de la Constitution fédérale de la Confédération suisse, edited by Jean-François Aubert and Pascal Mahon, 1023-1027. Zurich, Basel, Geneva: Schulthess, 2003.

Aubert, Jean-François. "Commentary on Art. 135 FedCst." In Petit Commentaire de la Constitution fédérale de la Confédération suisse, edited by Jean-François Aubert and Pascal Mahon, 1055-106o. Zurich, Basel, Geneva: Schulthess, 2003.

Aubert, Jean-François. "Commentary on Chapter 3 FedCst." In Petit Commentaire de la Constitution fédérale de la Confédération suisse, edited by Jean-François Aubert and Pascal Mahon, 998-1001. Zurich, Basel, Geneva: Schulthess, 2003.

Behnisch, Urs. "Commentary on Art. 127 FedCst." In Basler Kommentar, Bundesverfassung, edited by Bernhard Waldmann, Eva Maria Belser and Astrid Epiney, 2038-2062. Basel: Helbing Lichtenhahn, 2015.

Behnisch, Urs. “Commentary on Art.129FedCst." In Dieschweizerische Bundesverfassung, St. Galler Kommentar, edited by Bernhard Ehrenzeller, Benjamin Schindler, Rainer J. Schweizer and Klaus A. Vallender, 2330-2341. Zurich, St. Gallen: Schulthess, 2014.

Biaggini, Giovanni. Kommentar zur Bundesverfassung der Schweizerischen Eidgenossenschaft. Zurich: Orell Füssli, 2017.

Hänni, Peter. "Commentary on Art. 135 FedCst." In Basler Kommentar, Bundesverfassung, edited by Bernhard Waldmann, Eva Maria Belser and Astrid Epiney, 2138-2152. Basel: Helbing Lichtenhahn, 2015.

Reich, Markus. Steuerrecht. Zurich: Schulthess, 2012.

Simonek, Madeleine, "Commentary on Art. 129 FedCst." In Basler Kommentar, Bundesverfassung, edited by Bernhard Waldmann, Eva Maria Belser and Astrid Epiney, 2073-2088. Basel: Helbing Lichtenhahn, 2015.

Simonek, Madeleine. "Commentary on Art. 128 FedCst." In Basler Kommentar, Bundesverfassung, edited by Bernhard Waldmann, Eva Maria Belser and Astrid Epiney, 2062-2072. Basel: Helbing Lichtenhahn, 2015. 
Tschannen, Pierre, Ulrich Zimmerli and Markus Müller. Allgemeines Verwaltungsrecht. Bern: Stämpfli, 2014 .

Vallender, Klaus A. and René Wiederkehr, “Commentary on Art. 127 FedCst." In Die schweizerische Bundesverfassung, St. Galler Kommentar, edited by. Bernhard Ehrenzeller, Benjamin Schindler, Rainer J. Schweizer and Klaus A. Vallender, 22852316. Zurich, St. Gallen: Schulthess, 2014.

Vallender, Klaus A. and Ulrich Cavelti. "Commentary on Art. 128 FedCst." In Die schweizerische Bundesverfassung, St. Galler Kommentar, edited by Bernhard Ehrenzeller, Benjamin Schindler, Rainer J. Schweizer and Klaus A. Vallender, 2317-2329. Zurich, St. Gallen: Schulthess, 2014.

Wiederkehr, René and August Mächler. "Commentary on Art. 135 FedCst." In Die schweizerische Bundesverfassung, St. Galler Kommentar, edited by Bernhard Ehrenzeller, Benjamin Schindler, Rainer J. Schweizer and Klaus A. Vallender, 24032420. Zurich, St. Gallen: Schulthess, 2014. 